\title{
Language Variations of Teenagers: A Case Study in A Walk to Remember Film
}

\author{
Niswatin Nurul Hidayati \\ STAI Al Hikmah Tuban \\ Email: niswatinnh@gmail.com
}

\begin{abstract}
Research on the relationship between language and gender or language and age is included in the realm of sociolinguistic studies. In this research, the researcher focused on language variation in teen speech. Researchers used qualitative research methods with non-interactive data collection methods. From the findings and analysis, the researcher concluded that the form of utterances used by the teenagers were different depending on their gender. The depth of this difference was seen in the frequency of slang vocabulary usage and the vernacular form of language that was more often used by young men. Gender differences turned out to affect the form of utterance of these adolescents where even though they were in the same group, adolescent girls still paid attention to the value of "prestige" in their language. In contrast to young men who show more their masculinity through slang and vernacular forms of language. In addition, the family and social environment, as well as their age where adolescence is a period of exploration, also influence their speech patterns."
\end{abstract}

Keyword: language variations, case study, walk to remember

\section{BACKGROUND}

Language plays an important role in human social life because it is used as a communication tool in everyday life. Aside from being a communication tool, language is a means that shows self-identity and social class. In linguistics, the study of the relationship of language with self-identity and social class is discussed more deeply in sociolinguistics. Sumarsono said that sociolinguistics is a study of language that is associated with social conditions. ${ }^{1}$ Talking about social conditions, it is inseparable from gender issues, in this case related to how language is used by men and women in social life.

Holmes mentions "The linguistic forms are used by women and men in contrast - to different degrees - in all speech communities". ${ }^{2}$ It was also stated that there was an assumption that women had speech that was more polite than men. There are several examples of research on the differences in speech in men and women. Japanese society has differences in the utterance of some nouns, where women use word patterns that begin with the prefix $\neg 0$ - which is considered to show modesty on. Besides that, there are some differences in the vocabulary

\footnotetext{
${ }^{1}$ Sumarsono. Sosiolinguistik. (Yogyakarta: Pustaka Belajar, 2007)

${ }^{2}$ Janet Holmes. An Introduction to Sociolinguistics. (New York: Longman Publishing, 1995)
} 
used as in the words ohiya (water), onaka (stomach), oisii (delicious), and taberu (eat) used by women, while men use (mizu, hara, umai, kuu).

Other research has also been conducted in the English-speaking community on words ending in -ing [in] on the words swimming, typing, speaking, walking, killing, and others. In studies in the Norwich community, the results show that the male group uses the vernacular [in] more than the female group in the vocabulary. Besides changing the saying of the suffix [in] to [in], men also make a lot of sounds [h] at the beginning of words, as in Hall's words.

There are several reasons why men and women use different forms of language, they are social status, the role of women in society, social status of women as subordinate groups, speech functions that show masculinity. ${ }^{3}$ These reasons form the basis for writers to explore different linguistic variants, especially in adolescent groups.

There were some researches conducted related to the teenagers language variations, one of them was The Language of British Teenagers. A Preliminary Study of Its Main Grammatical Features written by Ignacio M. Palacios Martinez. In this research, the writer focused on some of the most distinctive features of the lexico-grammar of this language, using data mainly from COLT (Bergen Corpus of London Teenage Language) and from the SCOSE corpus (Saarbrücken Corpus of Spoken English) plus other supplementary materials. At times, comparisons are made with a comparable sample of adult language extracted from the DCPSE (Diachronic Corpus of Present-Day Spoken English). The analysis here examines those lexicogrammatical properties which distinguish teenagers' language from the language of adults. Under discussion will be, among others, the following grammatical features: the verbal and pronoun systems, the use of non-canonical tags, the system of negation, quotatives, the expression of vague language, ways of intensifying language and the use of abuse and insult words as vocatives. ${ }^{4}$

Another research was conducted by Indra and Hamzah with the title pf An Analysis of Language Style of Teenagers Found in Facebook Status. This research found that there were language styles used, they were formal, consultative, casual and intimate. The casual style is mostly used by the speaker with the percentage of $70 \%$. Furthermore, the writer found that the causes of casual is mostly used by facebook users. ${ }^{5}$

\footnotetext{
${ }^{3}$ Janet Holmes. An Introduction to Sociolinguistics. (New York: Longman Publishing, 1995)

${ }^{4}$ Ignacio M. Palacios Martinez. "The Language of British Teenagers. A Preliminary Study of Its Main Grammatical Features.” Atlantis, Journal of the Spanish Association of Anglo-American Studies, Juni, 2011. 33.1., ISSN 0210-6124.

5 Indra and Hamzah. "An Analysis of Language Style of Teenagers Found in Facebook Status". E-Journal of English Language and Literature Volume 7 No 1. Published by English Language and Literature Study Program of FBS Universitas Negeri Padang. ISSN 2302-3546.
} 
Then, related to differences of speech characteristics, there was a research conducted by Hidayati entitled Bahasa dan Gender: Kajian Karakteristik Kebahasaan Laki Laki dan Perempuan dalam Film Anak. This research aimed to describe the language features used by men and women characters used the language features proposed by Lakoff (1975), such as empty adjectives, hedge, intensifier, hypercorrect grammar, super polite form, tag question and emphatic stress, even though the characteristics of color words and question intonation have not been found in the characters' utterances. ${ }^{6}$

The object of the research was in the form of utterances from adolescent groups which was reflected in a film called $A$ Walk to Remember where the film tells the life of teenagers in North Carolina. In the analysis conducted, the writer compared the utterances of several characters in the film, such as Landon Carter, Jamie Sullivan, Belinda, Dean, Tracie and Eric to see the similarities and differences in the form of language used. The author uses film as a research tool because the film is a literary work that describes people's lives. This is like what Turner said that film is basically a mass media that is used to redisplay the reality that occurs in the social environment around us. Unconsciously, film is a representation of reality in society. ${ }^{7}$

Based on the background above, there were two things discussed in this paper, which are related to the different utterances used by young men and young women in $A$ Walk to Remember film, as well as the factors that influence the different utterances used by young men and women in A Walk to Remember film. Referring to the focus of the research above, the purpose of this research was to provide a description of the different utterances used by young men and young women in A Walk to Remember film, as well as analyzing the factors that influence the different utterances used by the young men and women in this film.

\section{Sociolinguistics}

In terms of names, sociolinguistics (SL) concerns sociology and linguistics, therefore SL has close links with the two studies. Sumarsono also mentioned that sociolinguistics is the study of language that is associated with social conditions. The term sociolinguistics is also often referred to as institutional linguistics or language sociology. ${ }^{8}$

In his book entitled Introducing Sociolinguistics, Rajend Mesthrie mentions that language is not just denotational, a term which refers to the process of conveying meaning, referring to

\footnotetext{
${ }^{6}$ Niswatin Nurul Hidayati. "Bahasa dan Gender: Kajian Karakteristik Kebahasaan Laki Laki dan Perempuan dalam Film Anak." Al Hikmah Jurnal Studi Keislaman Volume 6 Nomor 1, 2016. STAI Al Hikmah Tuban.

${ }^{7}$ Gramae Turner. Film as Social Practice. (New York: Routledge, 1999)

${ }^{8}$ Sumarsono. Sosiolinguistik. (Yogyakarta: Pustaka Belajar, 2007)
} 
ideas, events or entities that exist outside the language. While using language primarily for this function, a speaker will inevitably gve off signals concerning his or her social and personal background. He also added that language can be said to refer to social class, status, regional origin, gender, age group, and so on. ${ }^{9}$

Then, Halliday states that sociolinguistics (institutional linguistics) is related to the association of language with people who use that language. ${ }^{10}$ Whereas Holmes stated that "Sociolinguists study the relationship between language and society". He also added that sociolinguistics experts were interested in explaining the reasons why we speak utterances in different ways in social contexts and in identifying social functions of language. ${ }^{11}$ This opinion is also supported by Fishman's statement which called sociolinguistics as sociology of language, where he stated that:

"The sociology of language focuses upon the entire gamut of topics related to the social organization of language behavior, including not only language usage per se, but also language attitudes, overt behavior toward language and language users".

From some of the meanings conveyed by the experts above, the researcher can conclude that sociolinguistics is a branch of linguistics that examines the use of language in relation to social society, including in relation to social status.

\section{Language and Gender}

In the background section it has been mentioned that men and women use different forms of linguistics and it is assumed that women have more polite speech than men. Proof of this perception has been carried out in research both in western community groups (English speakers) and other community groups.

As far as the English-speaking community is concerned, experts have made the following pressures: (1) sociological research has shown that women are generally more aware of their position than men. This means that women realize that the better the language they use, the better their social position in society. (2) the working class has the connotation of masculinity or has something to do with virility, which results in men tending to prefer nonstandard forms of language compared to women. ${ }^{12}$

It was also stated that language diversity based on gender arises because language as a social phenomenon is closely related to social attitudes. This can be seen from the way the community is indeed a man and woman, where society hopes that a woman will speak "better

\footnotetext{
${ }^{9}$ Rajend Mesthrie. Introducing Sociolinguistics. (Edinburg: Edinburg University Press, 2001)

${ }^{10}$ Sumarsono. Sosiolinguistik. (Yogyakarta: Pustaka Belajar, 2007)

11 Janet Holmes. An Introduction to Sociolinguistics. (New York: Longman Publishing, 1995)

${ }^{12}$ Sumarsono. Sosiolinguistik. (Yogyakarta: Pustaka Belajar, 2007)
} 
and right" than a man. This statement is supported by Holmes who states that there are several reasons why men and women use different forms of language, namely social status, the role of women in society, social status of women as subordinate groups, speech functions that show masculinity. ${ }^{13}$

\section{The Utterance of Teenagers}

The variety of languages found in society is also influenced by the age factor where there are language groupings based on groups of children, adolescents, and adults. Adolescence is the most interesting time in human life because this period has the characteristics of adventure, grouping (clicks), and "delinquency". This is also reflected in the variety of languages used in the groups they form. ${ }^{14}$

\section{Age-Based Utterances Features}

Holmes states that the real difference in man and woman speech can be seen from their tone of voice where the tone of voice will further develop at their puberty. Sound quality in men and women also develops along with their physical development, where the lungs and head in men are bigger than women. As a result, the tone of a man's voice sounds lower than that of a woman, just as the tone of an adult's voice is deeper than a child's. ${ }^{15}$

The lower tone of voice in young men than women is a hallmark of the masculinity that they maintain along with the use of vernacular language they use. In addition to the tone of voice, there are also differences in vocabulary, pronunciation, and grammar that varies due to the influence of age. In their teens, many children get vernacular vocabulary in the form of "curse words" that they often use, but the use of the word will decrease with age. In women, "curse words" tend to be avoided in speech. ${ }^{16}$

\section{Research Method}

The researcher used descriptive qualitative research types. The data used in this research were words, phrases, clauses or sentences used by the characters in A Walk to Remember. Then, data collection techniques used by researchers were in two ways, they were non-interactive methods and interactive methods. Data collection techniques in qualitative research include: ${ }^{17}$

1. Non-interactive methods, which include questionnaires, recording documents or records, and observations do not play a role

\footnotetext{
${ }^{13}$ Janet Holmes. An Introduction to Sociolinguistics. (New York: Longman Publishing, 1995)

${ }^{14}$ Sumarsono. Sosiolinguistik. (Yogyakarta: Pustaka Belajar, 2007)

15 Janet Holmes. An Introduction to Sociolinguistics. (New York: Longman Publishing, 1995)

16 Janet Holmes. An Introduction to Sociolinguistics. (New York: Longman Publishing, 1995)

${ }^{17}$ H.B. Sutopo. Metode Penelitian Kualitatif. (Surakarta: Sebelas Maret University Press, 2002)
} 
2. Interactive methods, which include in-depth interviews, role observations and focus group discussions (FGD).

To analyze the data that has been obtained, researchers used content analysis techniques. In summary the steps to be taken by researchers in this study are: 1) watching films that have been selected as research objects; 2) transcription of the subtitles in the films; 3) choose the subtitles for films classified in the data needed in this study; 4) classifying data; 5) conduct data analysis; 6) draw conclusions.

\section{Discussion}

\section{Different Utterances of Teenagers}

As Holmes has said that the linguistic forms used by men and women are different. Adolescence is a period where teenagers get a lot of new vocabulary both standard and nonstandard, such as "curse vocabulary". Not infrequently they also create a variety of slang languages that they use in their groups. The following are some of the findings from the forms of utterances in adolescents that are reflected in A Walk to Remember film:

\section{Dialogue 1}

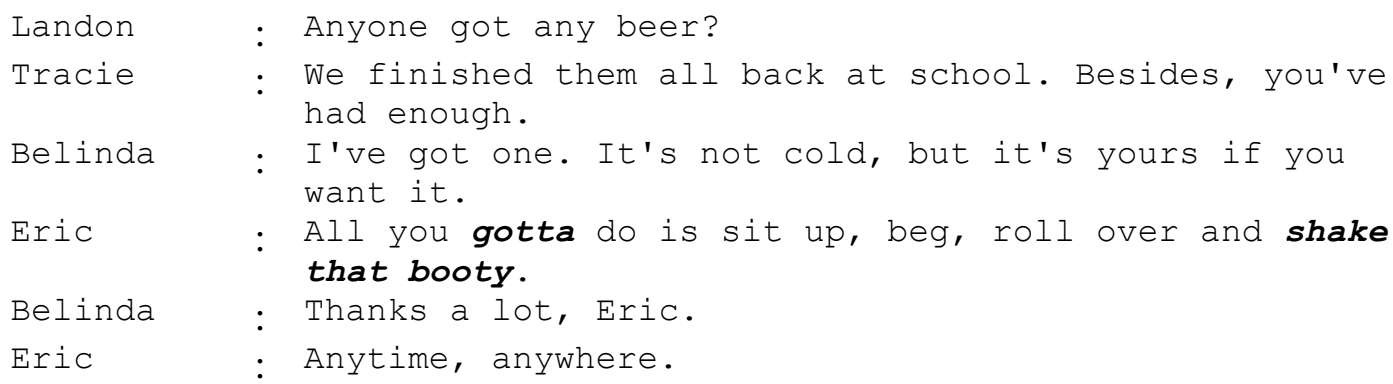

In the example above, it can be seen clearly the different forms of speech and different word choices between the Tracie, Belinda, Eric characters. Tracie and Belinda use non-formal speech forms in the form of You've (you have) and I've (I have), but these forms are forms that are used in everyday language in English-speaking countries. This is different from Eric's speech form where he uses slang word choices, like gotta and booty. The slang vocabulary gotta come from the word got to which means have to. In the Cambridge Dictionary, the word booty means "any valuable things or money stolen by an army at war or by thieves", but in slang, the word booty means bottom or buttock. If the utterances are compared, then the form of Tracie and Belinda utterances is "truer" than Eric's utterances.

\section{Dialogue 2}

Landon : This is gonna be sweet.

Belinda : I'm glad I thought of it. 


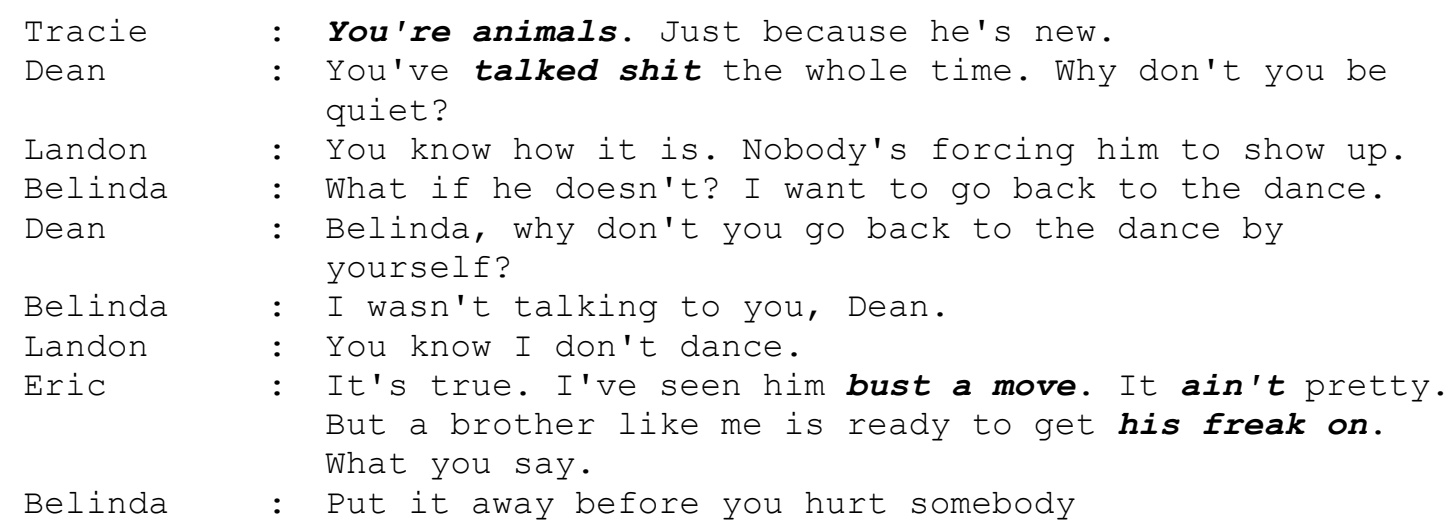

The example of the conversation above shows the form of utterance used by teenagers and their friends where there is vernacular and slang vocabulary. Although, young women use "swear words", but the intensity of their use is smaller than that of young men. In the example above, Tracie, also uses swear words in the form of "You 're animals", but Eric uses more slang vocabulary in his utterances such as "bust a move", "ain't", and "freak on". Then, when we look at the utterances used by Belinda in the example above, it will be seen that the utterances are "better" and "truer".

\section{Dialogue 3}

$\begin{array}{ll}\text { Landon } & \text { What is that? } \\ \text { Jamie } & \text { This is my telescope. I built it when I was } \mathbf{1 2 .} \\ & \text { Take a look. } \\ \text { Landon } & \text { Saturn. Very cool. } \\ \text { Jamie } & \text { I'm planning on building a larger one so I can see the } \\ & \text { comet Hyakutake. It comes this spring. Nobody knows } \\ \text { Landon } & \text { Nature's miracles. I get it. } \\ \text { Jamie } & \text { Get what? } \\ \text { Landon } & \text { That you're into all this stuff } \\ \text { Jamie } & \text { This stuff? } \\ \text { Jamie } & \text { I have my beliefs. I have faith, but don't you } \\ \text { Landon } & \text { No. There's too much bad shit in this world. } \\ \text { Jamie } & \text { Without suffering, there's no compassion. } \\ \text { Landon } & \text { Tell that to those who suffer. }\end{array}$

The sample conversation between Jamie and Landon above shows a slightly different picture from the previous conversation example where the character Landon uses the slang vocabulary. In the conversation above, he uses a "better" utterance as seen in the sentence "What is that?". This sentence is grammatically correct in English and formal. The same thing is also seen in Jamie's utterance "This is my telescope. I built it when I was 12 ". However, at the end of the conversation, it is seen that the character Landon uses a "rough" vocabulary, 
namely "bad shit". In this film, the word "shit" is indeed often used by Landon and other young men. However, in the conversation above Jamie did not say such a sentence this could be related to the context in which Jamie was the son of a priest. Besides that, the social environment between Landon and Jamie is very different, where Jamie is more struggling with social service activities, while Landon has a freer life.



In the last conversation, we will see footage of the conversation of 2 young male characters, Eric and Landon. It can be seen where they use the slang vocabulary, especially those spoken by Eric. These words include "hooters", "bullshit", and "big-booty". The word "hooters" is a form of slang which means "breast", while the phrase "big-booty" is a form of slang which means "big buttocks".

\section{Factors That Influence Speech Differences}

When we look back at some examples of conversations involving several teenage characters in the A Walk to Remember film above, it can be seen clearly that the form of utterances they use is different. Of course there are reasons why they use variations of these languages.

\section{The Influence of Age and Gender}

The author believes that adolescence is a period where adolescents have a high sense of curiosity and a period where a sense of "desire for recognition" arises. Sumarsono stated that adolescence is the most interesting time in human life because this period has the characteristics of adventure, grouping (clicks), and "delinquency". ${ }^{18}$ This is also reflected in the use of language where they often create the language they use in their groups or slang languages.

In their teens, many children get vernacular vocabulary in the form of "curse words" that they often use, but the use of the word will decrease with age. In women, "curse words" tend to be avoided in speech. ${ }^{19}$ Opinion expressed by Holmes is seen in the

\footnotetext{
${ }^{18}$ Sumarsono. Sosiolinguistik. (Yogyakarta: Pustaka Belajar, 2007)

${ }^{19}$ Janet Holmes. An Introduction to Sociolinguistics. (New York: Longman Publishing, 1995)
} 
frequency / frequency of using "curse word", where Landon, Eric and Dean use the word more than Belinda and Tracie. Whereas Jamie never uttered this vocabulary at all.

Although Belinda and Tracie have a pattern of free association and are in the same group as Landon, Eric and Dean, but they rarely and almost never use the word "curse". In this case the writer assumes that both of them still hold the aspect of "prestige" as a woman. This is consistent with what Sumarsono said that sociological research has shown that women are generally more aware of their position than men. ${ }^{20}$

Holmes stated that one of the reasons men use different languages than women is the reason for masculinity. ${ }^{21}$ This was also conveyed by Sumarsono that "the working class has the connotation of masculinity or it has to do with masculinity, which results in men tending to prefer non-standard forms of language compared to women". ${ }^{22}$ This can be seen in the utterances used by Landon, Eric and Dean where they are the most popular youth group in their school. As explained above, the utterances include "curse word" and slang, booty, bullshit, bad shit, bust a move, freak on, booters, ain't, gonna, big booty.

\section{The Influence of Environment and Family}

The author believes that in addition to age and gender, environmental and family factors also affect the form of speech of a teenager. Jamie Sullivan, Landon Carter, Belinda, Dean, Tracie and Eric are teenagers at one school in Beaufort, North Carolina. Landon, Belinda, Dean, Tracie and Eric are the most popular group of teenagers in school with free promiscuity. Landon was the son of a prominent doctor, but his parents had long since divorced so he only lived with his mother. Landon never wanted to meet his father because he thought his father had never loved him by choosing to divorce his mother. Belinda, Dean and Tracie have a free association without strong control from their parents. As for Eric, the writer assumes that he is a Black American group because it is not clearly explained in the film. Unlike them, Jamie was a daughter of a priest in the Beaufort area. Jamie was raised in a religious environment, in strict rules from his father, and had a different relationship with them. Jamie spent more time in social activities teaching children and attending school drama activities.

From their family background and social environment, of course this will affect the variety of languages they use. This can be seen in the utterances spoken by Jamie. It has a

\footnotetext{
${ }^{20}$ Sumarsono. Sosiolinguistik. (Yogyakarta: Pustaka Belajar, 2007)

${ }^{21}$ Sumarsono. Sosiolinguistik. (Yogyakarta: Pustaka Belajar, 2007)

22 Sumarsono. Sosiolinguistik. (Yogyakarta: Pustaka Belajar, 2007)
} 
"close to standard" form of language in which the grammatical structure used is complete or "near complete". Besides that, choosing the vocabulary used, Jamie never used slang vocabulary. As an example in his conversation with Landon, he uses "This is my telescope. I built it when I was 12 "and" I'm planning on building a larger one so I can see the comet Hyakutake. It comes this spring. Nobody knows when it'll be back."

\section{Conclusion}

From the findings and analysis above, the authors conclude that the form of utterances used by men and women are different, as are the boys and girls. The depth of this difference is seen in the frequency of slang vocabulary usage and the vernacular form of language that is more often used by young men. Gender differences turned out to affect the form of utterance of these adolescents where even though they were in the same group, adolescent girls still paid attention to the value of "prestige" in their language. In contrast to young men who show more their masculinity through slang and vernacular forms of language. In addition, the family and social environment, as well as their age where adolescence is a period of exploration, also influence their speech patterns.

\section{References}

A Walk to Remember Movie Script. Diakses dari laman http://www.veryabc.cn/movie/uploads/script/AWalktoRemember.txt pada tanggal 2 November 2013

Holmes, Janet. 1995. An Introduction to Sociolinguistics. Longman Publishing: New York Mesthrie, Rajend. 2001. Introducing Sociolinguistics. Edinburg University Press: Edinburg.

Sumarsono. 2007. Sosiolinguistik. Pustaka Belajar: Yogyakarta

Sutopo, H.B. 2002. Metode Penelitian Kualitatif. Surakarta: Sebelas Maret University Press.

Turner. Gramae. 1999. Film as Social Practice. New York: Routledge.

Martinez, Ignacio M. Palacios "The Language of British Teenagers. A Preliminary Study of Its Main Grammatical Features." Atlantis, Journal of the Spanish Association of Anglo-American Studies, Juni, 2011. 33.1., ISSN 0210-6124.

Indra and Hamzah. "An Analysis of Language Style of Teenagers Found in Facebook Status". E-Journal of English Language and Literature Volume 7 No 1. Published by English Language and Literature Study Program of FBS Universitas Negeri Padang. ISSN 2302-3546. 
Hidayati, Niswatin Nurul. "Bahasa dan Gender: Kajian Karakteristik Kebahasaan Laki Laki dan Perempuan dalam Film Anak." Al Hikmah Jurnal Studi Keislaman Volume 6 Nomor 1, 2016. STAI Al Hikmah Tuban. 